\title{
К ГЕОХИМИИ ПОЧВЕННЫХ УГЛЕВОДОРОДОВ СЕВЕРНОЙ ЭСТОНИИ
}

Настоящая работа является продолжением цикла исследований по биогеохимии Эстонского сланцевого бассейна $\left[{ }^{1-3}\right]$.

Нерастворимое органическое вещество Эстонского горючего сланцакукерсита, сформировавшегося в среднем ордовике, характеризуется высокой сохранностью фрагментов исходного биологического сырья [ $\left.{ }^{4}\right]$. Способом низкотемпературной деструкции нами установлено, что основная часть неразветвленных углеродных цепей в макромолекулах кукерсита насчитывает до 17 атомов углерода, цепи длиннее $\mathrm{C}_{12}$ содержат преимущественно нечетное число атомов углерода (рис. 1). Гипотетическая схема образования указанных цепей представлена в [5]. Кукерсит содержит небольшое количество битумоида (не более $0,6 \%$ от органического вещества), в том числе и нормальные парафины, у которых цепи более длинные и «нечетность» небольшая (рис. 1) [1,2]. Различия в составе связанных и свободных (парафиновых) углеродных цепей показывают, что они имеют разные источники происхождения.

Шахтные воды, омывающие пласты сланца, содержат углеводороды, состав которых в общих чертах близок к битумоидным (рис. 1), но имеются и более низкокипящие соединения с более высокой «нечетностью». Последние различия, а также обстоятельство, что в шахтных водах углеводородов часто значительно больше (до $100 \mathrm{~m} / \Omega$ ), чем позволяет их растворимость в воде, указывают на наличие другого источника происхождения, кроме сланца.

Кукерсит залегает на небольшой глубине (5-20 м), поэтому дождевые воды легко проникают в пласт сланца. Нами получены данные, что углеводороды подземных вод и седиментов сланцевого бассейна берут начало от почвенных липоидов, а также установлена сезонность образования почвенных углеводородов в течение вегетационного периода. Содержание липоидов - относительно низкомолекулярных веществ биологического происхождения - растворимых в неполярных и малополярных растворителях, составляет в почвенном гумусе $\left.5-20 \%{ }^{[6-9}\right]$.

Пробы для исследования отобраны в 1975 г. с поля около поселка Люганусе (Кохтла-Ярвеский район), которое находилось в 1 км севернее эрозионной границы распространения кукерсита. Глубина отбора проб 0-15 cм. Почва карбонатная, малокаменистая, содержание гумуса 4-4,5\%, pH 5,0. Поле было засеяно ячменем 17 мая, урожай собран в конще августа. В предыдущем году на поле было внесено орга- 


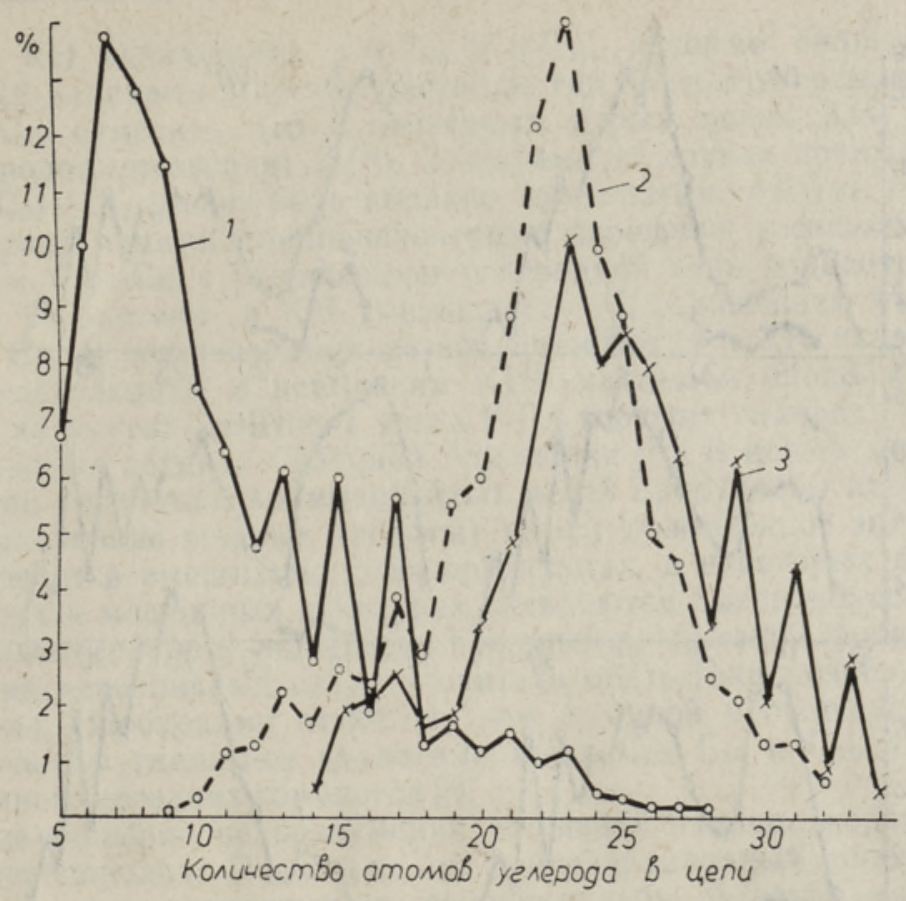

Рис. 1. Состав $н$-парафинов и н-парафиновых цепей органического вещества составляющих геосферы Северной Эстонии.

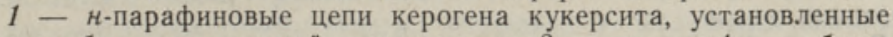
способом термической деструкцин, 2 - $H$-парафины битумонда кукерсита, 3 - н-парафины шахтных вод.

Таблия 1

Групповой состав почвенных липоидов, вес. $\%$

\begin{tabular}{c|c|c|c|c|c}
\hline $\begin{array}{c}\text { Месяц } \\
\text { отбора } \\
\text { проб }\end{array}$ & $\begin{array}{c}\text { Выход, } \\
\%\end{array}$ & $\begin{array}{c}\text { Алифати- } \\
\text { ческие } \\
\text { углеводо- } \\
\text { роды }\end{array}$ & $\begin{array}{c}\text { Алкил- } \\
\text { бензолы }\end{array}$ & $\begin{array}{c}\text { Полицикли- } \\
\text { ческая } \\
\text { ароматика }\end{array}$ & $\begin{array}{c}\text { Кислород- } \\
\text { ные соеди- } \\
\text { нения }\end{array}$ \\
\hline IV & 0,073 & 34 & 11 & 8 & 47 \\
V & 0,114 & 37 & 5 & 15 & 43 \\
VI & 0,119 & 34 & 4 & 17 & 45 \\
VII & 0,112 & 37 & 6 & 11 & 46 \\
VIII & 0.096 & 26 & 6 & 5 & 63 \\
XI & 0,086 & 23 & 14 & 11 & 52
\end{tabular}

нических удобрений 9 т/га. В течение вегетационного периода 1975 г. средняя температура воздуха превышала норму. Осадков весной было больше, а летом меньше, чем обычно. Урожайность нормальная.

Пробы брали в последнюю декаду каждого месяца (номер пробы в табл. 1 и 2 соответствует месяцу взятия очередной пробы). Воздушносухие образцы после удаления растительных остатков экстрагировали смесью спирт-бензол $(1: 1)$ в аппарате Сокслета в течение 24 . Полученные экстракты разделяли на группы соединений препаративной тонкослойной хроматографией $\left[{ }^{10}\right]$. Указанным способом, используя в качестве элюента петролейный эфир, алифатические углеводороды можно количественно отделить от других групп (см. табл. 1). Названия 


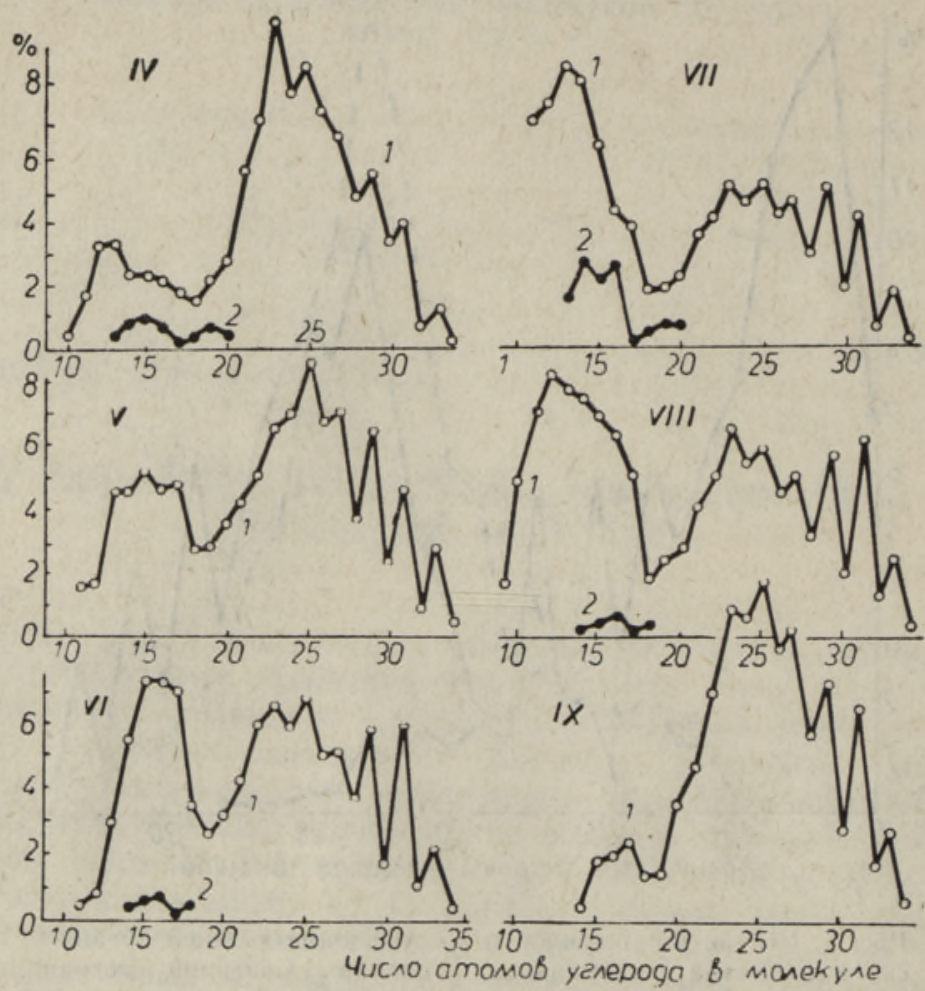

Рис. 2. Состав почвенных парафнновых углеводородов по месяцам (IV-XI) 1975 г.

1 - -парафины, 2 - изопреновые углеводороды.

групп являются условными: алкилбензолы содержат также стераны и тритерпаны, полициклическая ароматика - немного сложных эфиров; основные составляющие кислородных соединений известны как асфальтены и смолы. Индивидуальный состав углеводородов определяли газохроматографически на аппарате Хром-4, используя неподвижные фазы с различной полярностью.

По данным табл. 1 содержание липоидов в почве в течение года изменяется мало, в начале вегетационного периода и после него по понятным причинам их содержание несколько уменьшается.

Основные компоненты - кислородные соединения и парафины. Состав последних по месяцам приведен на рис. 2. Парафины имеют в основном нормальное строение, изопреновые углеводороды присутствуют в следовых количествах. Состав $\mathcal{H}$-парафинов характеризуется бимодальным распределением, концентрационный минимум находится при $\mu-\mathrm{C}_{18}$. Наличие большого количества низкокипящих углеводородов; образующихся в июне-августе при наивысшей интенсивности биологических процессов, было для нас неожиданностью.

Рассмотрим наиболее вероятные источники парафинов, разделяя их при этом на соответствующие группы с учетом коэффициентов нечетности (KН), т. е. соотношения концентраций $н$-парафинов с нечетным и четным числом атомов углерода, как это проводили Е. Е. Брей и Е. Д. Эванс [1']. Высокий КН указывает на происхождение непосредственно из высших растений, а низкий - на деятельность микроорганизмов или геохимические процессы деградацин. В наших пробах наи- 
больший $\mathrm{KH}$ наблюдался у $\mu$ - $\mathrm{C}_{29}$ и $H$ - $\mathrm{C}_{31}$, которые являются также основными алканами в восках растений, где КН часто превышает $15\left[{ }^{12}\right]$. Необходимо отметить, что в некоторых бурых углях КН указанных углеводородов превышает $3\left[{ }^{13}\right]$. В настоящем случае понижение КН в области $\mathrm{C}_{29}-\mathrm{C}_{32}$ может быть вызвано почвенными грибами и бактериями, продуцирующими длинноцепочечные парафины неселективно [ $\left.{ }^{14-16}\right]$. $\mathrm{B}$ области $\mathrm{C}_{23}-\mathrm{C}_{28}$ с укорочением углеродной цепи концентрации компонентов возрастают, а КН уменьшается. С дальнейшим укорочением цепи до $\mathrm{C}_{18}$ их концентрации резко понижаются и $\mathrm{KH}$ падает до единицы. Углеводороды с невысоким КН (максимум около $\boldsymbol{H}$ - $\mathrm{C}_{23}$ ) установлены во многих каменных углях $\left[{ }^{17}\right]$ и горючих сланцах $\left[{ }^{18}\right]$, а также в современных осадках Северной Атлантики [19]. В общей мировой биологической продукции прямолинейных цепей продуценты цепей $\mathrm{C}_{20}-\mathrm{C}_{24}$ (соответствующие жирные кислоты) имеют подчиненное значение. Они присутствуют в высших морских организмах, в некоторых диатомовых водорослях и масличных культурах и являются высоконенасыщенными. В настоящем случае указанные продуценты никакой роли не могут играть, их источниками следует считать опять-таки почвенные микроорганизмы. Необходимо отметить, что в одной пробе австралийской зеленой почвы главными кислотами были $\mathrm{C}_{22}, \mathrm{C}_{24}$ и $\mathrm{C}_{26}$, а также довольно много соседних гомологов [ $\left.{ }^{9}\right]$.

Самые большие недоразумения вызывает наличие короткоцепочечных углеводородов. Поскольку их концентрационный минимум находится у $\mathrm{C}_{18}$, они должны иметь особую судьбу. Следует иметь в виду, что соединения этой группы на открытом воздухе улетучиваются в течение нескольких дней, кроме того, в почве могут присутствовать также более низкокипящие соединения, которые в условиях нашего анализа не определялись. Во время наивысшей биологической продуктивности (июнь-август) они составляют основную часть почвенных углеводородов (табл. 1).

Источниками образования указанных углеводородов могут быть жобычные» жирные кислоты $\mathrm{C}_{14}-\mathrm{C}_{18}$ - основные источники прямолинейных цепей биологического происхождения. Но в таком случае возникает вопрос, почему их КН близок к единице, в то время как парафины $\mathrm{C}_{25}-\mathrm{C}_{31}$, имеющие также кислотное происхождение, характеризуются высоким КН. В настоящее время общепринято (хотя и не доказано), что парафины образуются из сложных эфиров кислот в результате окислительно-восстановительных процессов (промежуточно образуется $\beta$-карбонильная группа), при этом образующиеся парафины имеют на один атом углерода меньше ["1']. При образовании парафинов $<\mathrm{C}_{18}$ из кислот $\mathrm{C}_{14}-\mathrm{C}_{18}$ механизм их получения должен существенно отличаться. Это вполне возможно, если на процесс превращения оказывает влияние спиртовая часть эфиров, состоящая в случае кислот $\mathrm{C}_{14}-\mathrm{C}_{18}$ преимущественно из многоатомных, а в случае восковых кислот - из одноатомных спиртов, химические и физические свойства которых различны.

Указанные углеводороды, учитывая их КН, могут быть синтезированы микроорганизмами. Известно, что некоторые алканокисляющие дрожжи продуцируют парафины $\mathrm{C}_{16}-\mathrm{C}_{19}\left[{ }^{14}\right]$. C другой стороны, доля парафинов $<\mathrm{C}_{18}$ низка в холодное время, когда много $\mathrm{C}_{19}-\mathrm{C}_{25}$, которые, по-нашему мнению, синтезируются микробиологическим путем.

Представляем здесь еще один путь, который тоже является гипотетическим, а именно, образование из бифункциональных восковых кислот. Известно, что эти кислоты имеют два основных положення двойной связи гидроксильной или карбонильной группы - у 9-10 или 14-15 атомов углерода, считая от карбоксильной группы [20,21]. Если 
Распределение почвенных

\begin{tabular}{|c|c|c|c|c|c|c|c|c|}
\hline \multirow{2}{*}{$\begin{array}{l}\text { Месяц } \\
\text { отбора } \\
\text { пробы }\end{array}$} & \multicolumn{4}{|c|}{$\%$ от $н$-алканов } & \multicolumn{4}{|c|}{ Коэффициенты нечетности } \\
\hline & $<\mathrm{C}_{19}$ & $\mathrm{C}_{19}-\mathrm{C}_{22}$ & $\mathrm{C}_{23}-\mathrm{C}_{28}$ & $\mathrm{C}_{29}-\mathrm{C}_{34}$ & $<\mathrm{C}_{19}$ & $\mathrm{C}_{19}-\mathrm{C}_{22}$ & $\mathrm{C}_{23}-\mathrm{C}_{28}$ & $\mathrm{C}_{29}^{\prime}-\mathrm{C}_{34}$ \\
\hline $\begin{array}{r}\text { IV } \\
\text { V } \\
\text { VI } \\
\text { VII } \\
\text { VIII } \\
\text { XI }\end{array}$ & $\begin{array}{r}19 \\
29 \\
34 \\
47 \\
48 \\
8\end{array}$ & $\begin{array}{l}18 \\
16 \\
16 \\
11 \\
12 \\
17\end{array}$ & $\begin{array}{l}46 \\
41 \\
33 \\
29 \\
25 \\
54\end{array}$ & $\begin{array}{l}17 \\
14 \\
17 \\
13 \\
15 \\
21\end{array}$ & $\begin{array}{l}0,93 \\
1,15 \\
1,07 \\
1,07 \\
0,98 \\
1,04\end{array}$ & $\begin{array}{l}1,05 \\
0,92 \\
0,85 \\
1,02 \\
1,02 \\
0,92\end{array}$ & $\begin{array}{l}1,42 \\
1,23 \\
1,28 \\
1,23 \\
1,36 \\
1,23\end{array}$ & $\begin{array}{l}3,56 \\
4,31 \\
4,75 \\
4,05 \\
3,88 \\
3,43\end{array}$ \\
\hline
\end{tabular}

указанные кислоты $\left(\mathrm{C}_{30}, \mathrm{C}_{32}\right)$ декарбоксилируются и имеет место расщепление цепи у функциональной группы, то образуются цепи, содержащие 20-22 и 12-17 атомов углерода. Эта деградация (окислительное расщепление, затем восстановление в парафины), протекающая химическим или биологическим путем, проходит неселективно, что согласуется с низким КН почвенных углеводородов $<\mathrm{C}_{22}$ и хорошо объясняет концентрационный минимум при $\mathrm{C}_{18}$. Но имеются также противоположные аргументы. Из рис. 1 и табл. 2 следует, что в летних пробах углеводородов $<\mathrm{C}_{22}$ значительно больше, чем $>\mathrm{C}_{29}$, а как известно, восковые кислоты содержат только небольшое количество бифункциональных $\left[{ }^{20}\right]$. Таким образом, вопрос о путях образования углеводородов остается открытым.

Состав почвённых $\boldsymbol{H}$-парафинов сильно отличается от представленных в литературе данных $[7,15]$, согласно которым преобладают $\mathrm{C}_{29}, \mathrm{C}_{31}$ и $\mathrm{C}_{33}$. Только в одной зеленой австралийской почве установлены $\mathrm{C}_{17}-\mathrm{C}_{24}$, имеющие $\mathrm{KH}$, близкий к единице [15]. Углеводороды современных осадков Северной Атлантики $\left(\mathrm{C}_{20}-\mathrm{C}_{33}\right)$ имеют весьма сходный с почвенными алканами состав [19], подобен общий механизм их образования. Ни в одной пробе не установлены парафины $<\mathrm{C}_{18}$, но вполне возможно, что они затерялись в ходе анализа. Необходимо отметить, что парафины некоторых нефтей имеют такое же бимодальное распределение по длине цепи $\left[{ }^{22}\right]$ и более высокий КН в высококипящей части, какие наблюдаются и у почвенных парафинов.

Весьма интересен состав изопреновых углеводородов (см. рис. 2), присутствующих в небольших количествах. Их основным источником образования является фитольная боковая цепь молекулы хлорофилла. Известно, что в осадочных отложениях и в нефти главными изопреноидами являются фитан $\left(i-\mathrm{C}_{20}\right)$ и пристан $\left(i-\mathrm{C}_{19}\right)-$ наименее деградированные формы фитола $\left[{ }^{23}\right]$. В настоящем случае эти углеводороды отсутствуют или их концентрация не превышает концентрации $i$ - $\mathrm{C}_{13}-i$ - $\mathrm{C}_{18}$. Объяснение наблюдаемому несоответствию можно найти в работах недалекого прошлого, в которых исследованы диагенез органического вещества, в том числе и изопреноидов [24]. Оказывается, что на превращения фитола оказывает большое влияние двойная связь в непосредственной близости от гидроксильной группы. В восстановительных условиях превращения двойная связь гидрируется, далее возможно образование $i-\mathrm{C}_{20}$ и $i-\mathrm{C}_{19}$, но в окислительных условиях достоверно расщепление двойной связи с образованием кетона $i$ - $\mathrm{C}_{18}(6,10,14$-триметилпентадекан-2-он), который является также источником изопреноидов с более низким молекулярным весом. Таким образом, присутствие кислорода в почве обусловливает своеобразный состав его изопреновых углеводоро- 
дов. Нами установлено, что кероген кукерсита не содержит изопреновых структур [ $\left.{ }^{2}\right]$, по-видимому, это связано с окислительными условиями его образования $\left[{ }^{25}\right]$.

Результаты настоящей работы показывают, что состав почвенных углеводородов подвергается сезонному изменению и отличается от таковых из литературы. Для сравнения весной 1975 г. проанализированы также липоиды почвенных образцов, отобранных вблизи поселка Козе Харьюского района (пробы отбирала и анализировала Э. Урмет). Выделенные углеводороды отличались от предыдущих содержанием низкокипящих $\mathrm{H}$-1-олефинов, преимущественно четных $\mathrm{C}_{14}$ и $\mathrm{C}_{16}$, присутствие которых трудно объяснить. Пробы, собранные в начале 1976 г. там же, в отличие от всех остальных, содержали только «нечетные» н-парафины $\mathrm{C}_{27}-\mathrm{C}_{31}(\mathrm{KH}>10)$. Таким образом, состав почвенных углеводородов зависит от многих пока неизвестных факторов.

Наши результаты показывают близость состава углеводородов кукерсита и почвы. Кроме того, геологи сочли бы битумоид кукерсита, исходя из низкого содержания в нем углеводородов, сингенетичным $\left[{ }^{26}\right]$. Необходимо также отметить, что в одной работе по мягкому термолизу дебитуминированного кукерсита $\left[{ }^{27}\right]$ в начале деструкции из него образовались углеводороды, близкие к битуминоидным. В другой работе ['] такое явление не установлено. Очевидно, происхождение углеводородов кукерсита можно однозначно определить по геохронологическим данным по $\mathrm{C}^{14}$, учитывая, что эпигеничные углеводороды могли мигрировать в кукерсит только после последнего оледенения 10000 лет до н. э.

\section{Л И ТЕР А Т У Р А}

1. Уров К. Э., Клесмент И. Р., 1974. Превращение кукерсита при медленном термолизе в породных отвалах. Изв. АН СССР. Сер. Геол., № 6: 121-125.

2. Ряндур А. В., У ров К. Э., Клесмент И. Р., Эйзен О. Г., 1975. Углеводороды в прибалтийских горючих сланцах и смежных отложениях. Тез. докл. совещания «Горючие сланцы. Геохимия и литология», Таллин: $63-66$.

3. Клесмент И., Риккен Ю., У ров К., 1976. Особенности органического вещества диктионемовых сланцев. Бюл. «Горючие сланцы» № 6: 20-25.

4. Клесмен т И. Р., 1974. Роль жирных кислот при образовании некоторых сапропелитов. В сб.: Органическое вещество современных и ископаемых осадков, M.: $122-129$

5. Клесмент И., 1975. Алифатические углеродные цепи горючих сланцев. Структура и генезис. Изв. АН ЭССР. Хим. Геол., 24, № 2: 123-129.

6. Morris o n, R. I., B ick, W., 1967. The wax fraction of soils: separation and determination of some components. J. Sci. Food Agr., 18: 351-355.

7. Morris o n, R. I., 1969. Soil lipids. In: Organic geochemistry, Springer Verlag, Berlin: 553-575.

8. Аммосова Я. М., Орлов Д. С., Садовникова Л. К., 1973. Почвенные липоиды. В сб.: Природа органического вещества современных и ископаемых осадков, М.: $91-101$.

9. Stevenson, 1966. Lipids in soil. J. Amer. oil Chem. Soc. 43: 203-210.

10. Klesment, I., 1974. Application of chromatographic methods in biogeochemical investigations. J. Chromatog., 91: 705-713.

11. Bray, E. E., Evans, E. D., 1961. Distribution of n-paraffins as a clue to recognition of source beds. Geochim. Cosmochim. Acta, 22: 2.

12. Brooks, J. D., Smith, J. W., 1967. The diagenesis of plant lipids during the formation of coal, petroleum and natural gas. Changes in the $n$-paraffin hydrocarbons. Geochim. Cosmochim. Acta, 31: 2389-2397.

13. Гуляева Н. Д., Арефьев О. А., Соколов В. Л., Петров А. А., 1976. Закономерности распределения нормальных и изопреноидных алканов в углях различной стадии метаморфизма. Хим. тв. топлива, № 1: 106-110.

14. Дедюхина Э. Г., Андреев Л. В., Попков Г. П., Еротин В. К., 1972. Биосинтез углеводородов алканокисляющими микроорганизмами. Микробиология, 41, № 4: $664-667$.

15. Jones, J. G., 1969. Studies on lipids of soil micro-organisms with particular reference to hydrocarbons. J. gen. Microbiol., 59: 145-152. 
16. Dembicki, H., Meinschein, W. G., Hattin, D. E., 1976. Possible ecological and environmental significance of the predominance of even carbon number $\mathrm{C}_{20}-\mathrm{C}_{30} n$-alkanes. Geochim. Cosmochim. Acta, 40: 203-208.

17. Birkofer, L., Pauly, W., 1969. Caschromatographicshe und massenspektroskopische Untersuchung von Kohleextrakten. Brennstoffchemie, 50, Nr. 12: 376382 .

18. У р о в К. Э., 1975. Сравнительная характеристика спиртобензольного и эфирного экстрактов керогена кукерсита. Хим. тв. топлива, № 5: 66-67.

19. Шишенин а Е. П., Попова Н. В., Чернова Т. Г., Телков а М. С., Мор оз о в а Р. М., 1974. К геохимии углеводородов органического вещества современных осадков. Геохимия, № 8: 1212-1219.

20. Eglinton, G., H a milt o n, R. J., 1967. Leaf epicuticular waxes. Science, 156, No. 3780: $1322-1335$.

21. Stoianova-Ivanova, B., Mladenova, K., Popov, S., 1971. The composition and structure of ketones from rose bud and rose flower waxes. Phyto. chem., 10, No 6: 1391-1393.

22. Сергиенко С. Р., Кузовкова Т. С., Гарбалинский В. А., 1972. Концентрационное распределение н-парафинов в некоторых нефтях Советского Союза. АН ТуркССР. Сер. ФТХ и ГН, № 2: 22-27.

23. Солодков В. К., Драгунская В. С., Камьянов В. Ф., 1975. Изопреноидные углеводороды и генезис нефти. Изв. АН ТуркССР. Сер. ФТХ и ГН, № 3: $48-54$.

24. I k a n, R., B a ed e cker, M. J., K a p l a n, I. R., 1975. Thermal alteration experiments on organic matter in recent marine sediments - II. Isoprenoids. Geochim. Cosmochim. Acta, 39: 187-194.

25. Р а уд с еп п Х. Т., 1959. О генезисе эстонского горючего сланца кукерсита. В сб.: Генезис твердых горючих ископаемых, М.: 69-76.

26. Н ер уче в С. Г., 1962. Нефтепроизводящие свиты и миграция нефти, Л.: $30-35$.

27. Хотынцева Л. И., Бого молов А. И., Парпарова Г. М., С ак и. А., $\Phi$ а й з уллин а Е. М., 1974. Моделирование процессов катагенетического преобразования нерастворимой фракции сапропелевого органического вещества. В сб.: Органическое вещество современных и ископаемых осадков, М.: 138-149.

Ннститут химии

Академии наук Эстонской ССР

Поступила в редакцию 7/VII 1976

\section{KLESMENT, Neila LILLEP}

\section{PÖHJA-EESTI MULLA SUSIVESINIKE GEOKEEMIA}

On esitatud järeldus, et Põhja-Eesti muldades esinevad peamiselt $n$-parafiinid $\mathrm{C}_{10}-\mathrm{C}_{33}$ (enamikus bakteriaalset päritolu, kontsentratsiooni maksimumid asuvad $\mathrm{C}_{15}$ ja $\mathrm{C}_{24}$ kohal). Nende koostis muutub vegetatsiooniperioodi jooksul, lühikesed ahelad moodustuvad peamiselt suvel. Isoprenoidide seas on vähe pristaani ja fütaani.

\section{KLESMENT, Neila LILLEP}

\section{ON THE GEOCHEMISTRY OF NORTH-ESTONIAN EARTH HYDROCARBONS}

In the main, $n$-paraffins $\mathrm{C}_{10}-\mathrm{C}_{33}$ are present, mostly of bacterial origin, with maximum concentrations at $\mathrm{C}_{15}$ and $\mathrm{C}_{24}$. The composition of paraffins changes during the vegetation period; short chains are formed mostly in summer. Among isoprenoids there are negligible amounts of pristane and phytane. 